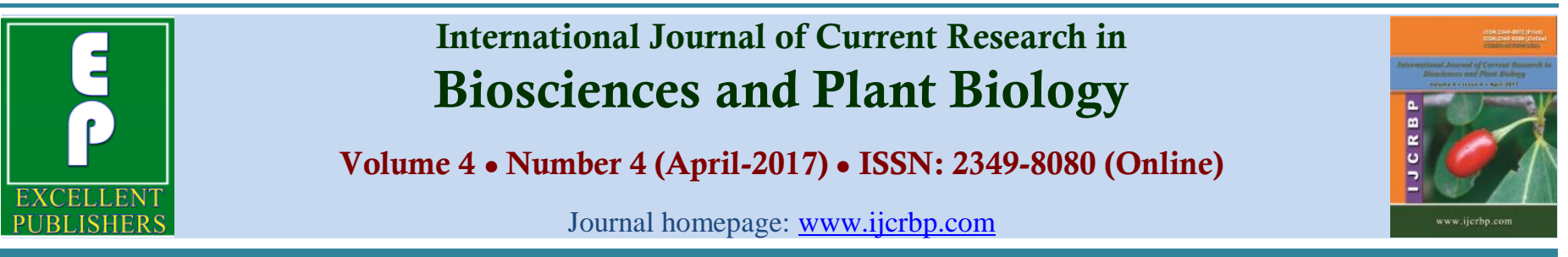

\title{
Floristic Diversity of Western Highlands Savannas of Cameroon
}

\author{
WOUOKOUE TAFFO Junior Baudoin*, NGUETSOP Victor Francois and FONKOU Théophile
}

Laboratory of Applied Botany, Department of Plant biology, Faculty of Sciences, University of Dschang, P. O. Box 67,
Dschang, Cameroon

*Corresponding author.

\begin{tabular}{|c|c|}
\hline Abstract & Article Info \\
\hline \multirow{9}{*}{$\begin{array}{l}\text { The savannas of the Western Highlands of Cameroon are exploited for agricultural and } \\
\text { pastoral activities. These savannas are still poorly studied and its sustainable management } \\
\text { requires knowledge in terms of flora. This study aimed to assess the floristic diversity of } \\
\text { savannas of the Western highlands of Cameroon. The basic data on the floristic } \\
\text { composition were collected to inventory plant diversity in } 72 \text { plots of } 100 \mathrm{~m}^{2} \text {. The species } \\
\text { richness and biological diversity indices were used to express diversity. In this study, } 260 \\
\text { flora species belong to } 165 \text { genera and } 72 \text { families were surveyed from April } 2013 \text { to } \\
\text { August } 2015 \text {. The most frequent and most abundant species were Imperata cylindrica and } \\
\text { Hyparrhenia involucrata. The families with the greatest number of species were Poaceae } \\
\text { (49); Asteraceae (35), Fabaceae (25), Rubiaceae (11), Hypericaeae (7) and Moraceae ( } 7 \text { ). } \\
\text { The Shannon diversity index (5.2), equitability of Pielou (0.97) and Simpson diversity } \\
\text { index (0.66) values were high. The great diversity of Western highlands savannas is linked } \\
\text { to the diversity of the observed biotopes. }\end{array}$} & $\begin{array}{l}\text { Accepted: } 12 \text { March } 2017 \\
\text { Available Online: } 06 \text { April } 2017\end{array}$ \\
\hline & Keywords \\
\hline & Diversity \\
\hline & Floristic composition \\
\hline & Highlands \\
\hline & Savannas \\
\hline & \\
\hline & \\
\hline & \\
\hline
\end{tabular}

\section{Introduction}

The knowledge of the flora and vegetation of a given locality is an essential tool to support the policies of sustainable development. The savanna biome covers approximately a fifth of the terrestrial area (Sankaran et al., 2005) including a large percentage in Africa (65\%) (Huntley and Walker, 1982). These ecosystems have a great ecological and economic importance. Savanna biome represents biodiversity hotspots, but also research has shown that they also sustain high levels of endemism (Barnard et al., 1998), support large human and animal populations (Happold, 1995; Scholes and Hall, 1996). These ecosystems display high levels of primary productivity when compared to other ecoregions and have a greater impact on the global carbon cycle than previously appreciated (Ojima et al., 1996; Houghton et al., 1999).

Beside Sub-Saharan Africa, Cameroon is one of the most biologically rich countries known up to date on the African continent (Sunderland et al., 2003). It encompasses an intricate mosaic of diverse habitats with moist tropical forest dominating the South and South east of the country, mountain forest and savanna in the highlands and the sub-Sahelian savanna in the far North (Sunderland et al., 2003). These diverse habitats harbour more than 9982 vascular plants species where 1000 species are endemic and 155 of them threatened (Onana, 2011). The majority of endemic taxa are concentrated 
around mount Cameroon and other highland areas.

Although the savannas are among the five plant habitats, plant inventory studies there have not been devoted exclusively to the montane savannas. Savannas, compared to the bigger part of closed forest, are easier to be converted to crop farms and their degradation is not considered as a serious environmental attack compared to the clearing of forests. Savannas have often been noticed to be epicentres of different destructive bushfires. The Western Highlands savannas of Cameroon which is a stronghold of montane biodiversity. The rugged topography and inaccessibility of the mountainous escarpment of the areas have resulted in a paucity of studies on its vegetation. These savannas, can also be strongly influenced by an increase of less destructive land use forms, above all grazing and selective logging of valuable tree species. Previous studies on the flora and vegetation of the Western highlands were fragmentary and relied on a qualitative description of the vegetation (Jacques-Félix, 1945; Portères, 1946; Letouzey, 1985). It is worth noting that a complete modern flora is still lacking.

The vegetation of the Western highlands occurs in various corners and the purpose of this study was to understand the present state of the ecosystem in order to provide conservation measures for the sustainability of floristic diversity.

\section{Materials and methods}

\section{Study site}

The study was carried out in the Bambouto and Mbapit mountains located in the Western highlands of Cameroon between $4^{\circ} 54^{\prime}-6^{\circ} 36^{\prime}$ North and $9^{\circ} 18^{\prime}$ $11^{\circ} 24^{\prime}$ East (Fig. 1). The herbaceous stratum is dominated by Pennisetum purpureum and Imperata cylindrica and ligneous cover is strongly influenced by anthropogenic activities (agriculture and pasture) (Letouzey, 1985). The climate is of the tropical Soudanian type, with a short dry season (from November - March) and a long rainy season (from March-November). The annual average rainfalls vary according to the relief from $1500-2600 \mathrm{~mm}$. The annual average temperature is about $20^{\circ} \mathrm{C}$. The predominant soils are the andosols, the ferralitic soils and eutrophic brown soils. Agriculture and pastures are the major activity and occupy the totality of land.

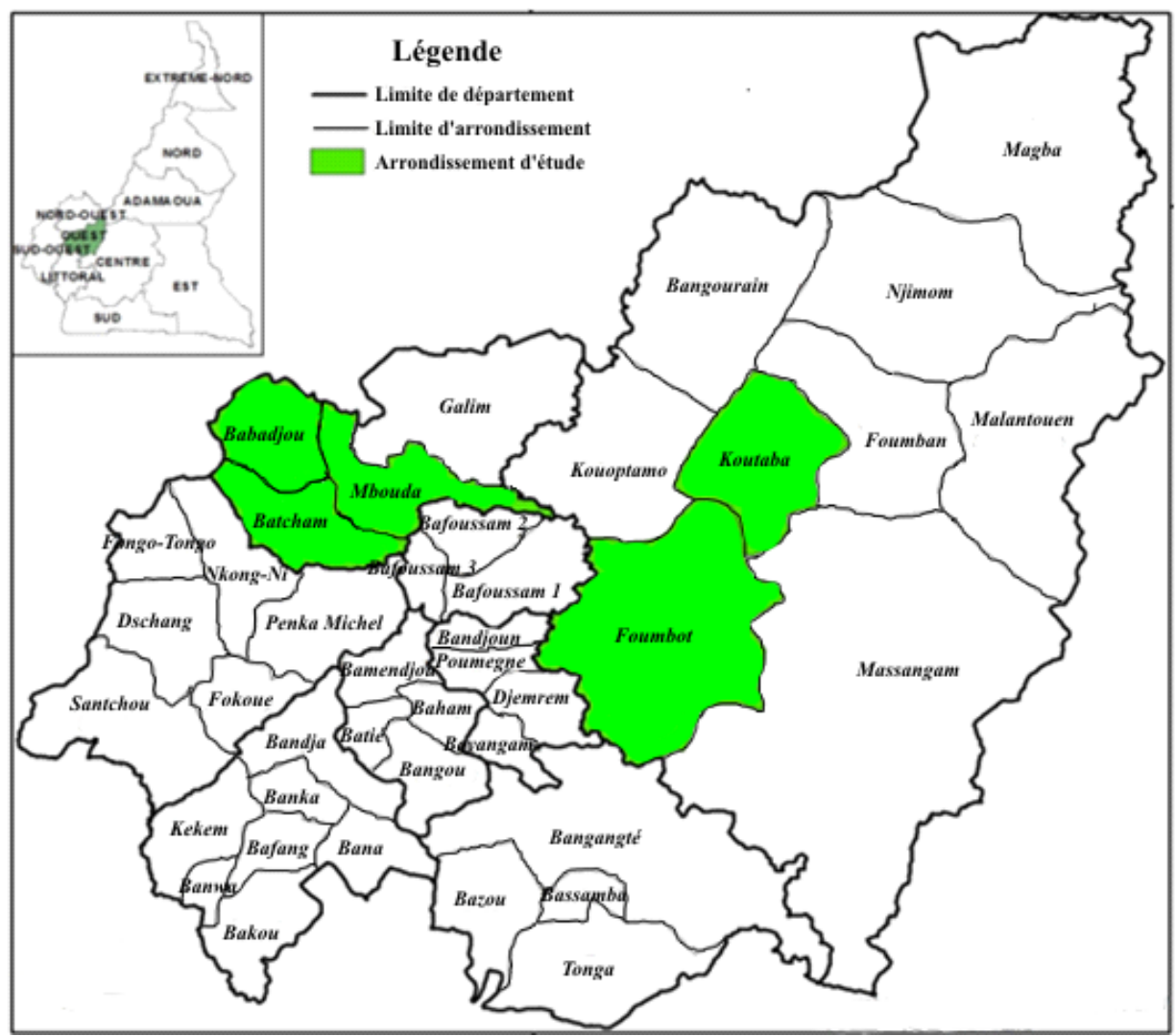

Fig. 1: Localization of study site in the West region of Cameroon. 


\section{Vegetation sampling}

The inventory was conducted from April 2013 to September 2015. Seventy-two quadrats of $100 \mathrm{~m}^{2}$ were randomly distributed in the altitudinal gradient from $1132 \mathrm{~m}$ to $2612 \mathrm{~m}$. Within each savanna, a quadrat of $100 \mathrm{~m}^{2}(10 \mathrm{~m} \times 10 \mathrm{~m})$ was laid for the inventory of woody components. Each plot was sub-divided into 5 sub-quadrats of $1 \mathrm{~m} \times 1 \mathrm{~m}$ placed at each angle and in the center of each quadrat for the inventory of the herbaceous species. The distance between two consecutive plots was $500 \mathrm{~m}$. Within each quadrat, all species were identified, topography, anthropogenic activities and geographical coordinates were recorded. When a taxon identification appeared uncertain in the field, more specimens were collected, dried and preserved for later identification in the Cameroon National Herbarium. The study parameters refer more particularly to the richness and floristic diversity.

\section{Vegetation analysis}

Species richness was calculated as the total number of species for the study site. The floristic diversity was calculated according to Simpson's diversity index formula, which takes into account both the number of species and their dominance: $\Delta^{\prime}=1-\sum(\mathrm{Ni} / \mathrm{N})^{2}$ Where $\mathrm{Ni}=$ strength of the species $\mathrm{i}, \mathrm{N}=$ total strength of all species. The Shannon-Weaver diversity index $\left(\mathrm{H}^{\prime}\right)$ was given by the formula: $\mathrm{H}^{\prime}=-\sum \mathrm{Ni} / \mathrm{N} \log _{2} \mathrm{Ni} / \mathrm{N}$ where $\mathrm{Ni}$ is the strength of the species "i" and $\mathrm{N}$ the strength of all species. The diversity equitability index of Pielou (Eq) was given by the formula: $\mathrm{E}=\mathrm{H}^{\prime} / \log _{2} \mathrm{~S}$ where $\mathrm{S}$ is the number of species in the survey. Equitability varies from 0 to 1 . It describes the distribution numbers of a different population species. The Margalef index (R) was given by the formula: $\mathrm{R}=\mathrm{S}-1 / \mathrm{ln} \mathrm{N}$ where $\mathrm{S}$ is the total number of species in the community and $\mathrm{N}$ the total number of individuals for all species in the studied community. Generic diversity index: $I G=\delta p / G$, where $\delta \mathrm{p}=$ number of species; $\mathrm{G}=$ number of genera the study population; IG = Generic diversity index. It helps to characterise the plant population stability (Sonke, 1998).

\section{Results and discussion}

\section{Floristic diversity parameters}

The The Shannon-Weaver diversity index (H') was 5.202 reflected high diversity of study site and the Pielou equitability index value was 0.667 . The Simpson diversity index value of 0.028 indicates that the probability of taking two individuals in the study site and for them to belong to the same species is weak. The Margalef index indicated 23.244 species per hectare in the studied area.

A rigorous examination of diversity requires a combination of relative abundance of species and the species richness of the studied area. The ShannonWeaver diversity index increases progressively when species diversity increases (Tagne, 2007). Thus, the high Shannon-Weaver's diversity index is 5.202 indicating high diversity of the studied savanna. This data is in coherence with the Pielou's equitability value which was 0.667 . The weak value of Pielou's equitability index expresses a dominance of the zone by some species. The values of Simpson's diversity index obtained in this study (0.098) is weak, then the probability that two individuals randomly selected belong to the same species is low. However, the Simpson diversity index value does not directly give an idea of diversity but rather the dominance index. It agrees to calculate the inverse of this index such that a high value of this index reflects a high diversity (Sonké, 1998).

In this work, the inverse of Simpson's diversity index was 0.902 and near the unity. High index reflects high diversity corresponding to favourable conditions of the milieu allowing the installation of numerous species. These species are generally represented by a small number of individuals (Dajoz, 1982). Thus, the mid zone is the richest but upper zone is the most diversified and most equitable at the level of the flora distribution. The high diversity of highlands savannas proven by values of various diversity indices is not surprising because Cameroon is one of the African countries having high biodiversity (Sunderland et al., 2003). This high diversity could also be due to the different studied biotopes (hollows, top of plateaux and slope zones) or the nutritional level of the milieu. At each topographic position corresponds a type of ground and specific type of drainage, which can constitute niches for various plant species.

\section{Floristic composition}

In this survey, a total of 263 species were recorded. Among these species, twelve could not be identified beyond the genus level, resulting in a total of 260 identified species belonging to 165 genera and 72 families (Angiosperms Phylogeny Group III). Recent 
data indicate that ten species met in the savanna belong to the IUCN red list species of Cameroon (Onana, 2011). Seven of these species are vulnerable "VU" and three belong to the category of the endangered "EN" species: Bafutia tenuicaulis (VU), Helichrysum cameroonense (EN), Vernonia guinensis (VU), Schefflera mannii (VU), Brachystelma omissum (VU), Impatiens sakerlana (VU), Lobelia columnaris (VU), Psorospermum aurentiacum (VU), Helictotrichon mannii (EN) and Sporobolus montanus (EN). This high number of species with particular ecological statute shows the need for the protection of these species.

\section{Specific level}

Two hundred and sixty (260) species were recorded in 72 sampling plots of $100 \mathrm{~m}^{2}$. Species composition over the total area was very heterogeneous. Only two species occurred in more than $44 \%$ of the plots and only six (Imperata cylindrica, Aspilia africana, Pteridium aquilinum, Vernonia guinensis and Erigeron floribondus in more than $25 \%$ of all plots (Table 1). A good proportion (94) species $(36.15 \%)$ are found only in one plot. Regarding relative abundance, Imperata cylindrica and Hyparrhenia involucrata with respectively $28.46 \%$ and $7.16 \%$ were the most abundant species in the study site. Fifty-three (53) species (13.07\%) are represented by less than 5 individuals; 11 species are represented by 2 individuals. The rare species having only individual represent $2.69 \%$ of total species included Canaruim schweinfurthii, Cyathea camerooniana, Dracaena arborea, Euphorbia heterophylla, Mangifera indica, Markhamia lutea and Psiduim guajava.

Table 1 lists the ten most important species in each relative parameter. Among the recorded species, some are endemic of the volcanic line of Cameroonian, these include: Erica manii (Ericaceae), Maesa lanceolatta (Myrsinaceae), Bafutia tenuicaulis (Asteraceae), Helichrysum cameroonense (Asteraceae), Digitaria adamaouensis (Poaceae), Helictotrichon mannii (Poaceae) and Sporobolus montanus (Poaceae) (Onana, 2011).

Table 1. Species with the highest values of relative frequency and relative abundance in descending order.

\begin{tabular}{llll}
\hline Species & Relative frequency & Species & Relative abundance \\
\hline Imperata cylindrica & 44.44 & Imperata cylindrica & 28.46 \\
Aspilia africana & 43.06 & Hyparrhenia involucrata & 7.16 \\
Pteridium aquilinum & 33.33 & Pennisetum purpureum & 6.24 \\
Vernonia guinensis & 29.17 & Pteridium aquilinum & 4.44 \\
Erigeron floribundus & 26.39 & Asplenium abyssinicum & 3.97 \\
Pennisetum purpureum & 25 & Pennisetum polystachion & 3.24 \\
Cyperus distans & 22.22 & Asplenium mannii & 2.48 \\
Asplenium abyssinicum & 22.22 & Aspilia africana & 1.70 \\
Terminalia glaucescens & 20.83 & Chromolaena odorata & 1.68 \\
Entada africana & 19.44 & Helichrysum cameroonense & 1.47 \\
\hline
\end{tabular}

The most frequent species were Imperata cylindrica and Aspilia africana. The importance of these species would be explained by ecological, geomorphological (slopes, low-slope, mid-slope and top) and climatic conditions of various plots. Moreover, the edaphic and anthropogenic conditions can also modulate in a significant manner the variation of the flora. The great abundance of Imperata in the studied area could be due to their great capacity of regeneration after bush fire and recent pastures. The presence of seven endemic species of the volcanic line of Cameroonian met in this study is not surprising. Indeed, the Western Highlands of Cameroon are part of the " 25 biodiversity hotspots", which are particularly rich, but also shelter many endemic species (Burgess et al., 2007).

\section{Genera level}

In this study, the relationship between the number of species and genus is equal to 1.59. This value is low and shows an average of less than two species by genus. The genera having more than one species are very few and their number generally decreases when the number of species increases.

A total of 165 genera were recorded in the study site. The Helichrysum and Vernonia genera had obtained the highest number of species (10). These were followed by the genera Ficus (7 species), Digitaria (6 species), Panicum (5 species), Psorospermum (5 species), Cyperus, Dissotis, Pennisetum and Sida with 4 species 
each. Eleven genera were represented by 3 species and twenty-two possess 2 species. The rest of the 122 remaining genera were represented only by single species. Two genera (Aspilia and Imperata) are found in 30 plots. Fifty-six (56) genera (33.93\%) are found only in one plot. The most abundant genus was Imperata with $28.47 \%$ of relative abundance. Ten most genera had obtained $71.78 \%$ of relative abundance and six genera were represented by only individual.

The species coefficient is an index that permits us to characterise the flora. This index sets in evidence the degree of isolation and the conditions in which plants populations have evolved (Evrad, 1968). The obtained value of the species coefficient in this work is low (1.59) meaning that the majority of the genus showed only one species in the plots. Thus, we can say that the flora of this savannah is relatively rich in species and more diversified in genera point of view. Therefore, we can assert that the flora of the different zones can be considered like stable on the geological time and does not undergo a phenomenon of speciation.

\section{Family level}

Seventy-two families were recorded in the sampling. More than $61.92 \%$ of the recorded taxa belong to only 11 species-rich families. The plant families with the highest number of genera and species in the studied area were those of the Poaceae (26 genera, 49 species); Asteraceae (14 genera, 35 species), followed by Fabaceae $(16,25)$, Rubiaceae $(8,11)$, Hypericaeae $(2$, $7)$, Moraceae $(1,7)$, Cyperaceae $(3,6)$, Malvaceae $(3,6)$, Euphorbiaceae $(4,5)$, Lamiaceae $(4,5)$ and Myrtaceae $(3,5)$. Thirty-eight families were represented only by a single species. Three families Poaceae, Fabaceae and Asteraceae are found in at least 52 plots. Eighteen families are found only in one plot. The most abundant families were Poaceae $(56.07 \%)$ and Asteraceae (16.34\%) (Table 2). Four families are represented only by one individual (Anacardiaceae, Bignoniaceae, Burseraceae and Cyatheaceae).

Table 2. Families with the highest values of relative frequency and abundance.

\begin{tabular}{llll}
\hline Family & Relative frequency & Family & Relative abundance \\
\hline Asteraceae & 91.67 & Poaceae & 56.07 \\
Fabaceae & 79.17 & Asteraceae & 16.34 \\
Poaceae & 72.22 & Aspleniaceae & 6.45 \\
Basalminaceae & 43.06 & Dennstaediaceae & 4.55 \\
Hypericaceae & 38.89 & Fabaceae & 2.98 \\
Rubiaceae & 33.33 & Cyperaceae & 2.46 \\
Dennstaediaceae & 33.33 & Lamiaceae & 1.52 \\
Cyperaceae & 30.56 & Rosaceae & 1.02 \\
\hline
\end{tabular}

The most frequent, the most abundant and the most diversified families in the Western Highlands savannas of Cameroon were the Poaceae, the Asteraceae and the Fabaceae. The observation of the current study is falling in line with the study conducted by Huntley and Walker (1982) who found that, savannas ecosystems are generally dominated by grasses. The high species number of the Poaceae family should be due to the fact that a great portion of the studied area is today occupied by the pastures and crossed each year by bush fires. This could also be explained by the fact that these taxa have a very great possibility of tillering and higher speed of regeneration after the regular passage of fires (Salette, 1970). The abundance of Asteraceae can be attributed to their wide ecological range of tolerance, and to their high seed dispersal capability. Poaceae and Fabaceae offer a very significant potential to forage; which support the exploitation of savannas for pastorals ends. A comparison of families in terms of the largest number of species recorded in this investigation and in similar studies revealed an agreement with such studies, e.g., Overbeck et al. (2006) in southern Brazil; Akossoua et al. (2010) in littoral cord Port-Bouët-Grand-Bassam Ivory Coast and Wouokoue (2014) in the Bambouto mountain's, West Cameroon. These three families also occupy the first position as for their species richness and appear among the greatest plants families in the planet (Craven, 2009). The Poaceae is the fifth family most diversified flowerings plants and the second most diversified family of the Monocotyledons (APG III). The Asteraceae and Fabaceae are respectively the second and third greatest families of the flowerings plants after Orchidaceae (Mabberley, 1997; Lewis et al., 2005). 


\section{Conclusion}

The objective of this study was to evaluate the floristic diversity of the Western Highlands savannas of Cameroon. The floristic inventories carried out on 72 plots of $100 \mathrm{~m}^{2}$ shows 260 plant species distributed in 165 genera, belonging to 72 families. The specific composition of the highlands savannas is diversified with 23.244 species per hectare. The most frequent species are Imperata cylindrica and Aspilia africana. The importance of these species would be explained by ecological, geomorphological, edaphic and anthropogenic conditions of various plots. The families of Poaceae, Asteraceae and Fabaceae are the most frequent, most abundant and most diversified in species. The biocenotic indices showed that, the greatest specific diversity observed in this study should be related to the biotopes diversity. The high values of the ShannonWeaver diversity index, Simpson diversity index and Pielou equitability obtained in this study permit to affirm that this savanna is rich and diversified

\section{Conflict of interest statement}

Authors declare that they have no conflict of interest.

\section{Acknowledgement}

The authors thank IDEA WILD that donated some equipment for the field data collection.

\section{References}

Akossoua, F.K., Adou, Y.C.Y., Ipou, J.I., Kamanzi, K., 2010. Diversité floristique des zones côtières pâturées de la Côte d'Ivoire : Cas du cordon littoral Port-Bouët-Grand-Bassam (Abidjan). Sci. Nature. 7(1), 69-86.

Barnard, P., Brown, C.J., Jarvis, A.M., Robertson, A., Van Rooyen, L., 1998. Extending the Namibian protected area network to safeguard hotspots of endemism and diversity. Biodivers. Conserv. 7(4), 531-547.

Burgess, N.D., Balmford, A., Cordeiro, N.J., Fjeldså, J., Küper, W., Rahbek, C., Sanderson, E.W., Scharlemann, J.P.W., Sommer, J.H., Williams P.H., 2007. Correlations among species distributions, human density and human infrastructure across the high biodiversity tropical mountains of Africa. Biol. Conserv. 134, 164-177

Craven, P., 2009. Phytogeographic study of the
Kaokoveld Centre of Endemism. Ph.D. Dissertation, University of Stellenbosch. 233p.

Dajoz, R., 2003. Précis d'écologie. Dunod, Paris. 615p.

Evrad, C., 1968. Recherche écologique sur le peuplement forestier des sols hydromorphes de la cuvette congolaise. Puplication I.N.E.A.C. Série scientifique $110.295 \mathrm{p}$.

Happold, D. C. D., 1995. The interactions between humans and mammals in Africa in relation to conservation: A review. Biodivers. Conserv. 4(4), 395-414.

Houghton, R.A., Hackler, J.L., Lawrence, K.T., 1999. The US carbon budget: Contributions from land-use change. Science. 285(5427), 574-578.

Huntley, B.J., Walker, B.H., 1982. Ecology of Tropical Savannas. Ecological Studies 42. Springer Verlag, Berlin. pp.101-119.

Jacques-Félix, H., 1945. Une réserve botanique à prévoir au Cameroun. Le sommet des Monts Bamboutos. Bulletin Museum National Histoire Naturel de Paris, Série 2 H. pp.506-513.

Letouzey, R., 1985. Notice de la carte phytogeographique du Cameroun au 1/500 000. Domaine de la forêt dense humide toujours verte. Institut de la carte internationale de la végétation. Toulouse France. pp.27-62.

Lewis, G., Shrire, B., Mackinder, B., Lock, M., 2005. Legumes of the world. Royal Botanic Gardens, Kew. 592p.

Mabberley, D.J., 1997. The Plant Book. A Portable Dictionary of the Vascular Plants. $2^{\text {nd }}$ Edn. Cambridge University Press. 858p.

Ojima, D.S., Valentine, D.W., Mosier, A.R., Parton, W.J., Schimel, D.S., 1993. Effect of land use change on methane oxidation in temperate forest and grassland soils. Chemosphere. 26, 675-685.

Onana, J.M., 2011. The Vascular Plants of Cameroon. A Taxonomic Checklist with IUCN Assessments. Compiled and Edited by Jean Michel Onana. 195p.

Overbeck, G. E., Müller, S. C., Pillar, V. D., Pfadenhauer J., 2006. Floristic composition, environmental variation and species distribution patterns in burned grassland in southern Brazil. Braz. J. Biol. 66(4), 1073-1090.

Portères, R., 1946. Climat et végétation de la chaîne des monts Bambuttos (Cameroun). Bull. Soc. Bot. France. 93, 352-360.

Salette J.O., 1970. Les cultures fourragères tropicales et leurs possibilités d'intensification. Fourrages. 43, 91-105. 
Sankaran, M., Ratnam, J., Hanan, N.P., 2004. Tree-grass coexistence in savannas revisited - insights from an examination of assumptions and mechanisms invoked in existing models. Ecol. Lett. 7, 480-490.

Scholes, R. J., Hall, D.O., 1996. The Carbon Budget of Tropical Savannas, Woodlands and Grasslands. SCOPE-Scientific Committee on Problems of the Environment International Council of Scientific Unions. 56, 69-100.

Sonke, B., 1998. Etude Floristique et Structurale des Forêts de la Réserve de Faune du Dja (Cameroun). Thèse de Doct, Univ Libre de Bruxelles. 267p.
Sunderland, T.C.H., Comiskey, J. A., Besong, S., Mboh, H., Fonwebon, J., Dione, M.A., 2003. Vegetation Assessment of Takamanda Forest Reserve, Cameroon. Smithsonian institution, SV. pp.19-53.

Tagne, T.G.A., 2007. Etude Floristique et Structurale des Ligneux de la Forêt Submontagnarde de la Colline Messa (Yaoundé). Mémoire de DEA, Université de Yaoundé 1. 58p.

Wouokoue, T.J.B., 2014. Composition floristique et phénologie des écosystèmes de savanes des monts Bambouto. Thèse de Master of Science, Université de Dschang. 72p.

\section{How to cite this article:}

Wouokoue Taffo, J. B., Nguetsop, V. F., Fonkou, T., 2017. Floristic diversity of Western Highlands savannas of Cameroon. Int. J. Curr. Res. Biosci. Plant Biol. 4(4), 7-13. doi: https://doi.org/10.20546/ijcrbp.2017.404.002 